\title{
The Naturalistic Response to Scepticism
}

\author{
RUTH WEINTRAUB
}

Hume is sometimes thought to provide a 'naturalistic' response to the sceptic. I consider two ways in which this response may be construed. According to the first, the fact that we are psychologically determined to hold a belief provides it with justification. According to the second, 'natural' beliefs provide limits within which reason can legitimately be employed, limits which the sceptic transgresses when he attempts to defend his position. Both versions of the naturalistic response to scepticism, I will argue, aren't plausible. And they aren't, at least not predominantly, Hume's.

\section{II}

According to the first version of naturalism, the psychological necessity of a belief endows it with justification. How is it supposed to do that?

The naturalist inverts a well-known normative principle, 'Ought implies can' (OIC). If one cannot do $\mathrm{x}$, then it is false that one ought to do $\mathrm{x}$. Since we cannot avoid believing $\mathrm{p}$, the naturalist reasons, it is permissible to believe it. 'Must implies permitted', or even 'must implies ought'. ${ }^{1}$

Does the psychological necessity provide us with justification? Does it invalidate charges of irrationality? The normative principle on which an affirmative reply is based, OIC, is very plausible in ethics, although it has come under attack even here. ${ }^{2}$ So let us grant that one is only held to blame for doing something if one could have done otherwise. But is the requirement that there be alternatives a plausible one when the assessment is epistemological?

${ }^{1}$ F. Wilson, 'Hume's Defence of Science'. Dialogue 25 (1986), 611-28.

2 H. Frankfurt, 'Alternate Possibilities and Moral Responsibility', Fournal of Philosophy 66 (1969), 829-39, and E. Schlossberger, 'Why we are Responsible for our Emotions', Mind 91 (1986), 37-56. 


\section{Ruth Weintraub}

Many philosophers reply affirmatively. Price notes Hume's distinction between 'sensible or sober or sane beliefs on the one side, and silly or superstitious beliefs on the other', ${ }^{3}$ and thinks it is inconsistent with Hume's holding belief to be involuntary. ${ }^{4}$ Flew thinks that 'when Hume claims that [belief] is 'unavoidable' ... he seems to be leaving no room for the possibilit[y] ... of legitimately criticizing people for holding irrational beliefs'.

Underlying philosophers' acceptance of OIC as epistemologically constraining beliefs is a view of justification 'as having to do with obligation, permission, requirement, blame, and the like', 6 a conception which Alston aptly labels 'deontological'. Thus, Chisholm suggests 'that every person is subject to a purely intellectual requirement: that of trying his best to bring it about that for any proposition $\mathrm{p}$ he considers, he accepts $\mathrm{p}$ if and only if $\mathrm{p}$ is true'. ${ }^{7}$ Bonjour thinks 'the idea of being epistemically responsible in one's believings $\ldots$ is the core of the notion of epistemic justification'. ${ }^{8}$ For Ginet, a person is justified in a belief, p, iff he 'could not be justly reproached for being confident that $\mathrm{p}$ ', ${ }^{9}$ and Wright thinks that to 'say that a man is justified in having a belief is to grant to him the right to be sure'. ${ }^{10}$

OIC is a plausible constraint when beliefs are appraised morally. If this is so, and if beliefs aren't voluntary, we will object to Clifford's claim that it 'is wrong always, everywhere, and for every one, to believe anything upon insufficient evidence'. ${ }^{11}$ We can, to be sure, lament the fact that people believe against the evidence (the world would be a better place if they didn't), but it is misguided to censure them.

${ }^{3}$ H. H. Price, Belief (London: George Allen and Unwin, 1969), 239-40.

${ }^{4}$ Op. cit., 239.

${ }^{5}$ A. Flew, Hume's Philosophy of Belief (London: Routledge and Kegan Paul, 1961), 98.

${ }^{6}$ W. Alston, 'The Deontological Conception of Epistemic Justification', in Epistemic Fustification (Ithaca: Cornell University Press, 1989), 115.

${ }^{7}$ R. Chisholm, Theory of Knowledge, 2nd edition (Englewood Cliffs, New Jersey: Prentice-Hall, 1977), 14.

${ }^{8}$ L. Bonjour, The Structure of Empirical Knowledge (Cambridge: Harvard University Press, 1985), 8, my italics.

9 C. Ginet, Knowledge, Perception, and Memory (Dordrecht: Reidel, 1975), 8, my italics.

${ }^{10}$ J. P. Wright, The Sceptical Realism of David Hume (Minneapolis: University of Minnesota Press, 1983), 11, original italics.

${ }^{11}$ W. K. Clifford, 'The Ethics of Belief', in Lectures and Essays, Vol. II. (London: Macmillan, 1879), 186. 


\section{The Naturalistic Response to Scepticism}

This doesn't mean that we will endorse Clifford's opponents, who claim that believing in accordance with the evidence may be inappropriate when other, moral, considerations outweigh truth. Some philosophers think that a person ought to believe that a loved one is innocent of a crime, even if the evidence is quite compelling, and would ordinarily constitute adequate grounds for taking them to be guilty, even sufficient for convicting them in a court of law. And, in a more impersonal vein, it is said that we should have a general positive bias towards mankind. Adams, for instance, claims ${ }^{12}$ that one ought to 'think charitably of other people ... to require less evidence to think well of them then to think ill of them, and thus, in some cases, not to proportion the strength of one's belief to the strength of the evidence'. ${ }^{13}$ These non-evidentialists are mistaken, but not because the pursuit of truth is the only morally defensible doxastic aim, but because being involuntary, beliefs cannot be morally criticized at all.

Things are quite different when it comes to epistemic criticism, since OIC isn't here a plausible constraint. A person who is psychologically bound to believe is absolved from (moral) guilt as is a person who is compelled to perform some action. But if he believes 'compulsively', and cannot be swayed by reason, he is deemed irrational, the more so the stronger the grip of his compulsion. So the naturalist, who thinks that unavoidable beliefs are justified, is mistaken.

This seems to me the most effective argument against the 'deontological' conception of justification. It is, for instance, very contentious to argue, as does Plantinga, ${ }^{14}$ that an 'epistemically blameless' true belief (caused by a clever hologram, for instance) doesn't constitute knowledge, since this relies on an analysis of knowledge-true justified belief-which is almost universally acknowledged to have been discredited by Gettier. ${ }^{15}$

Kornblith suggests that 'if a person has an unjustified belief, that

${ }^{12}$ R. M. Adams, 'Moral Arguments for Theistic Belief', Rationality and Religious Belief, C. F. Delaney (ed.) (Indiana: Notre Dame, 1979), 130.

${ }_{13}$ This seems to me a misconstrual of charity. If truly believing that someone has performed some action engenders-via a moral principletoo harsh a judgement, the moral principle is false. If charity is the correct attitude, the true moral principles and factual beliefs will enable us to judge leniently. Epistemology and morality needn't conflict.

${ }^{14}$ A. Plantinga, 'Positive Epistemic Status', Philosophical Perspectives 2 (1988), 1-50.

${ }^{15}$ E. Gettier, 'Is Justified True Belief Knowledge?', Analysis 23 (1963), $121-3$. 


\section{Ruth Weintraub}

person is epistemically culpable. ${ }^{16}$ This is simply to conflate morality and epistemology. In branding someone's belief irrational, we are, to be sure, unfavourably assessing him. But this is relative to an epistemic standard. So we are not blaming him, just as we are (typically) not blaming someone when we say he is a bad pianist; some evaluative judgments do not involve blame or praise.

Bonjour, too, seems to assimilate epistemology to morality. 'To accept a belief in the absence of ... a reason [for thinking it is likely to be true]', he suggests, 'is to neglect the pursuit of truth. Such acceptance is ... epistemically irresponsible' ${ }^{17}$ Let us grant that the pursuit of truth is a moral duty, either because the truth is intrinsically worthy, or because, as Clifford thinks, ${ }^{18}$ every belief will 'leave its stamp upon our character for ever'. Truths 'which have ... stood in the fierce light of free and fearless questioning ... [help] to bind men together, and to strengthen and direct their common action ... Every hard-worked wife of an artisan may transmit to her children beliefs which shall knit society together, or rend it in pieces'. ${ }^{19}$ 'The danger [false beliefs pose] to society is not merely that it should believe wrong things ... but that it should become credulous ... [and] sink back into savagery' ${ }^{20}$

Insofar as the pursuit of truth involves voluntary actions, people may be morally criticized for failing to carry them out. They may be censured for voluntarily corrupting their capacity to reason (by taking drugs, for instance), for willingly subjecting themselves to a process of indoctrination, and for not conducting their inquiries impartially-for collecting evidence selectively, so as to confirm a preconception. ${ }^{21}$ But the beliefs they form as a result of engaging in such intellectual ruses will be epistemically unjustified, rather than morally blameworthy.

Irrationality, I conclude, may be ascribed to unavoidable beliefs. In a marked contrast to moral evaluation, the epistemological kind doesn't bring prescription in its wake. ${ }^{22}$ So the naturalistic response

${ }^{16}$ H. Kornblith, 'The Psychological Turn'. Australasian Fournal of Philosophy 60 (1982), 243.

${ }^{17}$ Op. cit., 8, my italics.

${ }^{18}$ Op. cit., 182.

${ }^{19}$ Op. cit., 183.

${ }^{20}$ Op. cit., 186.

${ }^{21}$ See Alston, op. cit.

${ }^{22}$ So if Hume 'is trying to persuade us ... to set aside' (Passmore, 1977, 91, my italics) suspect beliefs, he must think it possible for us to do so, although not necessarily, pace Passmore, as a result of 'deliberately prevent[ing] ourselves from believing' (1977, 91). Effective persuasion, 


\section{The Naturalistic Response to Scepticism}

to the sceptic fails. We aren't epistemically justified in virtue of being compelled to believe.

\section{III}

The term 'naturalist' can be construed in a way which definitely renders it applicable to Hume. He 'attempt[s] to introduce the experimental method of reasoning into moral subjects'. In accounting for the way certain fundamental beliefs arise, his method is the one adopted in the natural sciences. He aims to form a "notion [of the mind] ... from careful and exact experiments, and the observation of those particular effects, which result from its different circumstances and situations'. ${ }^{23}$ And his theory will only appeal to 'natural' features of the human mind: instincts, propensities and habits. But Hume, I will argue, doesn't offer a 'naturalistic' response to scepticism.

Hume certainly thinks that the sceptical arguments are psychologically ineffectual. We can neither believe the sceptical conclusion, nor suspend belief in the propositions on which it casts doubt. 'A Pyrrhonian cannot expect, that his philosophy will have any constant influence on the mind' ${ }^{24}$ '[T] $T$ he sceptic still continues to reason and believe, even tho' he asserts, that he cannot defend his reason by reason'. ${ }^{25}$ 'Nature, by an absolute and uncontroulable [sic] necessity has determin'd us to judge as well as to breathe and feel'.$^{26}$ It is not just that we cannot control (not even indirectly) our 'natural' beliefs; they cannot even be changed as a result of persuasion or reflection.

${ }^{23}$ D. Hume, A Treatise of Human Nature, L. A. Selby-Bigge. (ed.), 2nd edition (Oxford: Clarendon Press, 1975), xvii.

${ }^{24}$ D. Hume, Enquiries Concerning Human Understanding, L.A. SelbyBigge (ed.), 3rd edition (Oxford: Clarendon Press, 1978), 160.

${ }^{25}$ D. Hume, A Treatise of Human Nature, 187.

${ }^{26}$ D. Hume, A Treatise of Human Nature, 183.

whether rational or not, merely requires that one's interlocutor come to see things in the desired way as a result of one's effort. The same is true of critical reflection on one's beliefs. When Hume describes himself as 'weigh[ing] the one miracle against the other.... and pronounc[ing] his decision' (1777, 116, my italics), Passmore thinks he 'decide[s] to believe that the testimony is false' (1977, 89 , original italics). I think Passmore is misinterpreting Hume. The 'decision' here is a verdict, or conclusion, and not a choice. 


\section{Ruth Weintraub}

But conceding the necessity of a belief doesn't suffice to make someone a naturalist. He must also take this psychological fact as constituting a rebuttal of the sceptic. If the answer isn't to be an admission of defeat, but rather, an attempt to show the sceptic's doctrine to be false, the psychological fact must be construed as $a$ ground for an anti-sceptical conclusion. The sceptic, it will allege, is either ignoring an important condition-voluntariness-for imputations of irrationality, or failing to note that the beliefs he criticizes do not satisfy it.

Wilson imputes to Hume such a naturalistic response to scepticism. 'Hume used ... the principle that must implies ought, the principle that the reasonable man will make a virtue out of necessity. Precisely because one must make causal inferences, it is only reasonable or proper that one do so'. ${ }^{27}$ Butler thinks that Hume considers belief in God a 'natural belief', and hence justified. ${ }^{28}$ Gaskin also ascribes the naturalistic position to Hume. ${ }^{29}$ 'Hume's doctrine of natural belief allows that certain beliefs are justifiably held by all men without regard to the quality of the evidence which may be produced in their favour ... [such as the] belief in an external world'.$^{30}$

Millican, too, thinks Hume is a naturalist. He ascribes to him the claim that we 'can see ... no reason whatever why induction should be a reliable method for inference ... [but] cannot help taking for granted that the past is a reliable guide to the future ... hence we should treat induction as our norm of factual reasoning'. ${ }^{31}$

Is Hume a naturalist in this sense? He isn't, Lenz thinks, ${ }^{32}$ because if he were, he would be committed to thinking that all beliefs are justified, since they are all causally determined. And, Lenz (rightly) says, Hume classifies some beliefs-superstitions, for instance-as irrational.

There are two objections that can be leveled against this argu-

${ }^{27}$ Op. cit., 616, original italics, footnote omitted.

${ }^{28}$ R. J. Butler. 'Natural Belief and the Enigma of Hume', Geschichte der Philosophie 42 (1960), 73-100.

${ }^{29}$ But Gaskin doesn't think Hume takes the religious belief to be natural.

${ }^{30}$ J. C. A. Gaskin, 'God, Hume and Natural Belief', Philosophy 49 (1974), 281.

${ }^{31}$ P. Millican, 'Hume's Sceptical Doubts concerning Induction', Reading Hume on Human Understanding, P. Millican (ed.) (Oxford University Press, 2002), 166.

${ }^{32}$ J. W. Lenz, 'Hume's Defense of Causal Inference', Hume, Chappell, V. C. (ed.) (Notre Dame: University of Notre Dame Press, 1966), 174. 
ment, the first of which can, perhaps, be met. There is no textual evidence for imputing to Hume a deterministic view of belief. In defending the view that human actions are determined by motives, he invokes his regularity theory of causation to show that (deterministic) causation in the mental realm is possible. '[I]n judging of the actions of men we must proceed upon the same maxims, as when we reason concerning external objects. When any phaenomena are constantly and invariably conjoin'd together, they acquire such a connexion in the imagination, that it passes from one to the other' ${ }^{33}$ ' $[\mathrm{T}]$ his uniformity forms the very essence of necessity'. ${ }^{34}$

But in order to show that some mental phenomenon is, in fact, causally determined, one must show that the requisite regularity does obtain. 'We must ... shew, that as the union betwixt motives and actions has the same constancy, as that in any natural operations, so its influence on the understanding is also the same, in determining us to infer the existence of one from that of another. If this shall appear ... we cannot, without a manifest absurdity, attribute necessity to the one, and refuse it to the other'. ${ }^{35}$ And, indeed, he goes on to show that actions do manifest regularity. 'The ... prisoner, when conducted to the scaffold, foresees his death as certainly from the constancy and fidelity of his guards as from the operation of the ax or wheel'. ${ }^{36}$

Hume nowhere says that the requisite regularities can be found so as to ground a deterministic view of belief in general. True, he thinks that we are causally determined to make inductive inferences. But we also (improperly) 'form general rules, and allow them to influence their judgment, even contrary to present observation and experience' ${ }^{37}$ And this might be thought to ground the naturalistically constrained distinction between reasonable (causally determined) and unreasonable (superstitious) belief.

We can, perhaps, save Lenz's argument by insisting that even superstitious belief is for Hume causally determined, since it is caused, and Humean causality is deterministic. Superstition, Hume thinks, ${ }^{38}$ 'proceeds from those very principles, on which all judgments concerning cause and effects depend ... [C] ustom sometimes ... has an effect on the imagination in opposition to the

${ }^{33}$ D. Hume, A Treatise of Human Nature, 403.

${ }^{34}$ D. Hume, A Treatise of Human Nature, 403.

${ }^{35}$ D. Hume, A Treatise of Human Nature, original italics, my underlining.

${ }^{36}$ D. Hume, A Treatise of Human Nature, 406.

${ }^{37}$ D. Hume, $A$ Treatise of Human Nature, 147.

${ }^{38}$ D. Hume, A Treatise of Human Nature, 147-8, my italics. 


\section{Ruth Weintraub}

judgment, and produces a contriety in our sentiments concerning the same object' ${ }^{39}$

The second, and more powerful, reason for rejecting Lenz's reductio argument is that even if Hume were a naturalist who took belief to be causally determined, he could still draw a distinction between justified and unjustified beliefs, because he doesn't identify 'determined' with 'unfree'. As a compatibilist about free will, he thinks true 'liberty ... is oppos'd to violence ... [and doesn't mean] a negation of necessity and causes'. ${ }^{40}$ So he can quite consistently view a causally determined belief as free, and classifiable as irrational. Of course, such a classification isn't possible if beliefs are involuntary, but that is a different argument.

There are, however, two more compelling reasons for thinking that Hume doesn't offer a naturalist response to the sceptic. First, he thinks that 'all [the sceptic's] arguments ... admit of no answer ... [even if they] ... produce no conviction'. ${ }^{41}$ And second, when defending a belief, or an inference rule, Hume never merely cites its naturalness. There are several such occasions.

Our (natural) beliefs, Hume thinks, are conducive to our survival. '[H]uman life must perish, were [the sceptic's] principles ... to prevail ... All discourse, all action would immediately cease; and men remain in a total lethargy, till the necessities of nature, unsatisfied, put an end to their miserable existence ... [Fortunately,] so fatal an event is very little to be dreaded. Nature is always too strong for principle'. ${ }^{42}$

The 'operation of the mind, by which we infer like effects from like causes ... is so essential to the subsistence of all human creatures, it is not probable, that it could be trusted to the fallacious deductions of our reason ... It is more conformable to the ordinary wisdom of nature to secure so necessary an act of the mind, by some instinct or mechanical tendency, which may be infallible in its operations ... As nature has taught us the use of our limbs, without giving us the knowledge of the muscles and nerves, by which they are actuated; so has she implanted in us an instinct, which carries for-

${ }^{39}$ Hume also refers to the causes of association, which he thinks is indeterministic. 'This uniting principle among ideas is not to be consider'd as an inseparable connexion ... we are only to regard it as a gentle force, which commonly prevails' $(1739,10)$. This inconsistency can be eliminated by supposing that he thinks there are additional conditions of a different kind (perhaps even non-mental) which jointly with the associative principles render association deterministic.

${ }^{40}$ D. Hume, A Treatise of Human Nature, 407.

${ }^{41}$ D. Hume, Enquiries Concerning Human Understanding, 155, fn. 1.

${ }^{42}$ D. Hume, Enquiries Concerning Human Understanding, 160. 
ward the thought in a correspondent course to that which she has established among external objects'. ${ }^{43}$

Here, again, it is the reliability of the natural mechanism which Hume cites by way of a recommendation. There 'is a kind of preestablished harmony between the course of nature and the succession of our ideas ... Had not the presence of an object instantly excited the idea of those objects, commonly conjoined with it, ... we should never have been able to adjust means to ends' ${ }^{44}$

Hume's defence of the belief in the existence of external bodies is, similarly, based on its efficacy. 'Nature has not left this to [our] choice, and has doubtless esteem'd it an affair of too great importance to be trusted to our uncertain reasonings and speculations' ${ }^{45}$ This (non-naturalistic) defence is, admittedly, puzzling. Hume doesn't explain why the belief in the continuing existence of objects is useful. And an explanation is certainly required, since he thinks that the belief is either unjustified or false.

It is unjustified if construed-in a 'philosophical' vein-as attributing existence to objects behind the 'veil of perception'. 'The only conclusion we can draw from the existence of one thing to that of another, is by means of the relation of cause and effect ... But as no beings are ever present to the mind but perceptions ... we ... can never observe it between perceptions and objects. 'Tis impossible, therefore, that from the existence of the former, we can ever form any conclusion concerning the existence of the latter' ${ }^{46}$

The vulgar identify objects with perceptions. Their belief in the continuing existence of objects, Hume thinks, is actually false. 'Tis a gross illusion to suppose, that our resembling perceptions are numerically the same'. ${ }^{47}$ '[V]ery little reflection and philosophy is sufficient to make us perceive the fallacy of that opinion'. ${ }^{48}$ Still, it is the belief's efficacy, and not its 'naturalness' that Hume cites by way of a justification.

Having conceded that the imagination is 'the ultimate judge of all systems of philosophy', ${ }^{49}$ Hume must justify the blame he attaches to the 'antient philosophers for making use of that faculty, and allowing themselves to be entirely guided by it in their reasonings' ${ }^{50}$

${ }^{43}$ D. Hume, Enquiries Concerning Human Understanding, 55.

${ }^{44}$ D. Hume, Enquiries Concerning Human Understanding, 54-5.

${ }^{45}$ D. Hume, A Treatise of Human Nature, 187.

${ }^{46}$ D. Hume, A Treatise of Human Nature, cit., 212.

${ }^{47} \mathrm{D}$. Hume, $A$ Treatise of Human Nature, 217.

${ }^{48}$ D. Hume, A Treatise of Human Nature, 210, my italics.

${ }^{49} \mathrm{D}$. Hume, A Treatise of Human Nature, 225.

${ }^{50}$ D. Hume, A Treatise of Human Nature, 225. 


\section{Ruth Weintraub}

In response, he distinguishes 'in the imagination betwixt the principles which are permanent, irresistible, and universal ... [a]nd the principles, which are changeable, weak, and irregular'. But it isn't the necessity which provides the justification. Hume goes on to suggest that the 'natural' principles 'are the foundation of all our thoughts and actions, so that upon their removal human nature must immediately perish and go to ruin. The ["unnatural"] ones are neither unavoidable to mankind ... or so much as useful in the conduct of life ... For this reason the former are received by philosophy, and the latter rejected'. ${ }^{51}$

That this is not a naturalistic justification is manifest in the metaphor Hume invokes to illustrate the normative distinction. 'One who concludes somebody to be near him, when he hears an articulate voice in the dark, reasons justly and naturally ... But one, who is tormented he knows not why, with the apprehension of spectres in the dark, may, perhaps, be said to reason, and to reason naturally too: But then it must be in the same sense, that a malady is said to be natural ... arising from natural causes, tho' it be contrary to health, the most agreeable and most natural situation of man'. ${ }^{52}$ Health may be typical, but more importantly, it is pleasant. It is no coincidence that Hume doesn't compare natural beliefs with death or aging, which are even more 'universal, irresistible and permanent' than health!

When Hume finally formulates a normative doxastic principle, he recommends that only ' $[\mathrm{w}]$ here reason is lively, and mixes itself with some propensity, it ought to be assented to. Where it does not, it can never have any title to operate upon us'. ${ }^{53}$ Isn't this is a naturalistic prescription? Not really. It doesn't identify 'justified' with 'natural'. A natural belief may be criticized as a result of reflection.

Here is another occasion in which Hume flouts the naturalistic counsel: he recommends philosophical speculations as against superstition (organized religion). Superstition 'arises naturally and easily from the popular opinions of mankind, it seizes more strongly on the mind'. ${ }^{54}$ But it is 'often able to disturb us in the conduct of our lives and actions. Philosophy on the contrary, if just, can present us only with mild and moderate sentiments; and if false and extravagant, its opinions are merely the objects of a cold and general speculation, and seldom go so far as to interrupt the course of our

${ }^{51}$ D. Hume, A Treatise of Human Nature, 225, my italics.

${ }^{52}$ D. Hume, $A$ Treatise of Human Nature, 226, my italics.

${ }^{53}$ D. Hume, A Treatise of Human Nature, 270.

${ }^{54}$ D. Hume, A Treatise of Human Nature, 271. 


\section{The Naturalistic Response to Scepticism}

natural propensities ... the errors in religion are dangerous; those in philosophy only ridiculous'. ${ }^{55}$

Philosophy isn't just 'safe'. If we shun 'hypotheses embrac'd merely for being specious and agreeable ... we might hope to establish a system or set of opinions, which if not true (for that, perhaps, is too much to be hop'd for) might at least be satisfactory to the human mind, and might stand the test of the most critical examination'. ${ }^{56}$ No appeal to naturalness here.

Lenz claims that 'for Hume justifying a belief meant showing that it is true'.$^{57}$ This, it should by now be clear, is simply false. Hume invokes other considerations, and even justifies beliefs whose truth he cannot vouchsafe. '[W]e might hope to establish a system or set of opinions, which if not true (for that, perhaps is too much to be hop'd for) might at least be satisfactory to the human mind'. ${ }^{58}$ But he never invokes a belief's inevitability by way of justification. He isn't, I conclude, a naturalist. ${ }^{59}$

\section{IV}

One may doubt the cogency of Hume's (non-naturalistic) responses to the sceptic. The sceptical arguments, Hume thinks, cannot be faulted. '[E]xperience will sufficiently convince any one, who thinks it worth while to try, that ... he can find no error in the [sceptical] arguments' ${ }^{60}$ And the scepticism to which they give rise is very radical. It is both 'unmitigated' (denying justification, and not merely knowledge) and sweeping (applying to all beliefs except those reporting one's immediate experience). As a result of the 'intense view of these manifold contradictions and imperfections in human reason ... [Hume] can look upon no opinion even as more probable or

${ }_{55}^{5}$ D. Hume, $A$ Treatise of Human Nature, 272, my italics.

${ }^{56} \mathrm{D}$. Hume, A Treatise of Human Nature, 272.

${ }^{57}$ Op. cit., 170.

${ }^{58}$ D. Hume, A Treatise of Human Nature, 272.

${ }_{59}$ Wittgenstein is not a naturalist in the sense I am considering. Admittedly, he suggests that our certainty about some propositions is 'something animal' (1969, para. 359). But they aren't epistemologically priviliged because they are unavoidable. Rather, they have a special linguistic role. It is inconceivable that we should be mistaken about them (1969, para. 54), because their truth is 'the test of [our] understanding' them (1969, para. 80, italics removed). 'If you are not certain of any fact', Wittgenstein suggests (1969 para. 114), 'you cannot be certain of the meaning of your words either".

${ }^{60}$ D. Hume, A Treatise of Human Nature, 184. 


\section{Ruth Weintraub}

likely than another' ${ }^{61}$ '[T] $\left[\right.$ he understanding', he thinks, ${ }^{62}$ 'when it acts alone, and according to its most general principles, entirely subverts itself, and leaves not the lowest degree of evidence in any proposition, either in philosophy or common life'. ${ }^{63}$

How can one who has endorsed the (radical) sceptical argument justify his claim that his beliefs are reliable, pleasant or harmless? And how can he 'propose a compleat system of the sciences ... upon which they can stand with ... security'? ${ }^{64}$ Hume says '[w]e may well ask, What causes induce us to believe in the existence of body?'. There is a marked contrast, he thinks, between this descriptive question and the normative one. '[T] is vain to ask, Whether there be body or not? That is a point, which we must take for granted in all our reasonings' ${ }^{65}$ But don't the sceptical arguments undermine his claim to justify his answer to the descriptive question?

'A true sceptic', Hume says, ${ }^{66}$ 'will be diffident of his philosophical doubts, as well as of his philosophical conviction; and will never refuse any innocent satisfaction, which offers itself, upon account of either'.

This is not a naturalistic response. Since the sceptical reasoning is 'forc'd and unnatural', ${ }^{67}$ the naturalist will have us ignoring it altogether; it can 'never have any title to operate upon us' ${ }^{68}$ So Hume has something else in mind: the fact that the sceptical doctrine applies to itself. It means that even if there is no way of faulting the sceptical argument, its (radical) conclusion must be tempered, engendering 'a more mitigated scepticism ... which may be both durable and useful ... The greater part of mankind are naturally apt to be affirmative and dogmatical in their opinions ... [Reflection about] the strange infirmities of human understanding ... would naturally inspire them with more modesty and reserve, and diminish their fond opinion of themselves' ${ }^{69}$ Hume, too, has

${ }^{61}$ D. Hume, A Treatise of Human Nature, 268-9, my italics.

${ }^{62}$ D. Hume, $A$ Treatise of Human Nature, 267-8, my italics.

${ }^{63}$ We needn't here decide whether Hume is a sceptic about induction (Stove, 1973; Stroud, 1977; Fogelin, 1985) or not (Baier, 1991; Garrett, 1997). Hume definitely presents an argument, invoking repeated assessments of the reliability of one's assignment of probabilities to propositions, whose sceptical conclusion is very radical: 'that all the rules of logic require a continual diminution, and at last a total extinction of...evidence' (1739, 183, my italics).

${ }^{64} \mathrm{D}$. Hume, A Treatise of Human Nature, xvi.

${ }^{65}$ D. Hume, A Treatise of Human Nature, 187.

${ }^{66} \mathrm{D}$. Hume, A Treatise of Human Nature, 273.

${ }^{67} \mathrm{D}$. Hume, A Treatise of Human Nature, 185.

${ }^{68}$ D. Hume, A Treatise of Human Nature, 270.

${ }^{69}$ D. Hume, Enquiries Concerning Human Understanding, 161. 


\section{The Naturalistic Response to Scepticism}

'fallen into this fault', but will now avoid using 'such terms as 'tis evident, 'tis certain' (p. 274). ${ }^{70}$ '[T] caution, and modesty, which, in all kinds of scrutiny and decision, ought for ever to accompany a just reasoner'. ${ }^{71}$ '[T] $[$ he learned ... amidst all the advantages of study and reflection, are commonly still diffident in their determinations'. ${ }^{72}$ 'True scepticism collapses into mere openmindedness' ${ }^{73}$

Is this the proper way to reflect the fact that radical scepticism applies to itself? Hume himself proposes a very different one when contending with the following (ancient) objection to the sceptical doctrine, couched in the form of a dilemma. 'If the sceptical reasonings be strong, 'tis a proof, that reason may have some force and authority; if weak, they can never be sufficient to invalidate all the conclusions of our understanding'.$^{74}$

The same dilemma is posed by Bourdin to Descartes' sceptic: if 'you had 'powerful and well thought-out reasons', ... why renounce them? ... If, on the other hand, they are doubtful and completely suspect, how have they managed to force or compel you?'. ${ }^{75}$ Sextus Empiricus, too, is aware of the difficulty. 'Yes, say [the dogmatists], but the argument which deduces that proof does not exist, being probative itself, banishes itself' ${ }^{76}$

Here is Hume's attempt to show that the sceptical position isn't self-defeating. Using reason, bowing to its authority, the sceptic undermines it from within. The sceptic provides an ad hominem argument, invoking premises accepted (and considered justified) by his non-sceptical opponent. From these premises he derives a sceptical conclusion, which his interlocutor will be forced to accept. Will such a sceptical argument constitute a reductio ad absurdum of reason? Not quite. We cannot hold steadfastly to the sceptical conclusion, because it undermines the premises and inference rules that led us to accept it. But reason isn't vindicated either. Hume ${ }^{77}$

${ }^{70}$ D. Hume, A Treatise of Human Nature, 187.

${ }^{71}$ D. Hume, Enquiries Concerning Human Understanding, 162.

${ }^{72}$ D. Hume, Enquiries Concerning Human Understanding, 161.

${ }^{73}$ A. C. Baier, A Progress of Sentiments (Cambridge, Massachusetts: Harvard University Press, 1991), 58.

${ }^{74}$ D. Hume, A Treatise of Human Nature, 186.

${ }^{75}$ R. Descartes, Philosophical Works of Descartes, J. Cottingham, R. Stoothoff and D. Murdoch (trans.) (Cambridge University Press, 1985), vol. II, 315.

${ }^{76}$ Sextus Empiricus, Against the Logicians, R. G. Bury (trans.) (London: W. Heinemann, 1935), 487.

${ }^{77}$ D. Hume, A Treatise of Human Nature, 186-7. 


\section{Ruth Weintraub}

beautifully characterizes the instability of the sceptical conclusion. Once the ascendancy of reason is undermined, the sceptical argument itself loses its force, and reason regains its throne, only to become vulnerable again to the sceptical threat, and so on, ad infinitum. The philosophical argument cannot be settled, even if it is cut short by nature, which forces on us beliefs whose justification is forever being brought into question. 'The sceptical and dogmatical reasons are of the same kind, tho' contrary in their operation and tendency; so that where the latter is strong, it has an enemy of equal force in the former to encounter; and as their forces were at first equal, they still continue so, as long as either of them subsists; nor does one of them lose any force in the contest, without taking as much from its antagonist'. ${ }^{78}$

So we have two very distinct responses to the fact that radical scepticism applies to itself. Which is the proper one? Is it possible, as the first response would have it, to accommodate the sceptical doctrine, or will the sceptical arguments, '[w]ere we to trust entirely to their self-destruction ... have subverted all conviction, and have destroy'd human reason'? ?9

The answer depends on the kind of sceptic we are responding to. There is, first, the daily sense of the term 'sceptic', applicable to one who claims that a proposition is unlikely to be true ('I am sceptical about peace in the Middle East'). In its radical form, this kind of scepticism alleges that most of our beliefs are (probably) false. According to the second-philosophical-kind of scepticism, they aren't justified. The crucial difference between the two sceptics is that the former thinks he knows the truth, whereas according to the latter it cannot be known. Our beliefs may well be true; but that will be mere luck.

Hume's optimistic diagnosis is pertinent when contending with the first sort of sceptic. To take a concrete example, suppose we are persuaded that $70 \%$ of our beliefs are false. This doxastic state is inconsistent: we believe the conjunction of our beliefs, yet also think that most of its constituents are false. If we can tell which beliefs are false, we can simply adopt their denials. But if we can't, we have to employ a more complicated strategy. Here is a (probabilistic) suggestion as to how we may render ourselves consistent in the face of this kind of sceptical challenge.

Choose a complete set of atomic propositions which we now believe, and assign probability 0.3 to each. This doesn't yet determine a complete (subjective) probability distribution; the

${ }^{78}$ D. Hume, A Treatise of Human Nature, 187.

${ }^{79}$ D. Hume, A Treatise of Human Nature, 178. 


\section{The Naturalistic Response to Scepticism}

probability of a Boolean combination isn't uniquely fixed by the probabilities of its constituents. There are many assignments which are consistent with the probability calculus. So choose one conservatively, minimising the shift from the (inconsistent) doxastic state we started out from. The resultant state of credence is coherent (i.e., it satisfies the probability calculus). In particular, it won't be 'selfdenigrating'.

There are obvious objections that could be raised at this point. Will Hume's (psychological) theory or his (non-naturalistic) defense of 'vulgar' beliefs come out as reasonably credible? And even if they do, won't a different choice of atomic propositions engender a very different (subjective) probability distribution which isn't so hospitable to Hume's intentions? And can't a given set of atomic propositions be conservatively extended in different ways, again, engendering very different outcomes?

We needn't consider these objections here. The procedure which they question is made in response to the wrong sort of sceptic, the one who claims to have a more accurate opinion than ours about the way things are. This is not Hume's sceptic. He claims that our beliefs are unjustifiable. '[T]he very same principles', he argues, 'which make us form a decision upon any subject ... must ... reduce [our evidence] to nothing, and utterly subvert all belief and opinion' ${ }^{80}$ Is there a rational way of accommodating $\mathrm{him}$, an alternative belief-system which we can adopt in response to his criticism of our present one?

Here is a suggestion made by Garrett. Hume first considers the possibility of 'sav[ing] ourselves from this total scepticism's1 by espousing an epistemological principle according to which we should reject all 'refin'd or elaborate reasoning'. ${ }^{82}$ He rejects this principle, because 'we ... cannot establish it for a rule, that [refin'd reflections] ought not to have any influence; which implies a manifest contradiction'. ${ }^{83}$ The rule is self-undermining, being itself the outcome of 'refin'd reflections'-the sceptical argument. Hume endorses, instead, the 'Title principle' ${ }^{84}$. 'Where reason is lively, and mixes itself with some propensity, it ought to be assented to. Where it does not, it can never have any title to operate upon us' ${ }^{85}$ This

${ }^{80}$ D. Hume, A Treatise of Human Nature, 184.

${ }^{81}$ D. Hume, A Treatise of Human Nature, 268.

${ }^{82}$ D. Hume, $A$ Treatise of Human Nature, 268.

${ }^{83}$ D. Hume, $A$ Treatise of Human Nature, 268.

${ }^{84}$ D. Garrett, Cognition and Commitment in Hume's Philosophy (Oxford: Oxford University Press, 1997).

${ }^{85}$ D. Hume, A Treatise of Human Nature, 270. 


\section{Ruth Weintraub}

principle is self-endorsing, being itself natural. 'We find ourselves believing $\ldots$ as if in accordance with [it]' ${ }^{86}$ And there are no 'lively reflections' which can undermine it. The sceptical argument is 'sufficiently refin'd and metaphysical' ${ }^{87}$

This strategy cannot avert the threat of 'total scepticism'. Selfratification may be a necessary condition for justification, but it certainly isn't sufficient. The following preposterous principles are self-ratifying: 'Believe only propositions which it takes more than 3 seconds to comprehend', 'Believe only contentious propositions', etc.

We must conclude that Hume is mistaken in thinking he can justify ordinary beliefs or 'propose a compleat system of the sciences, built on ... [the only foundation] upon which they can stand with any security' ${ }^{88}$ But his thought isn't naturalistically grounded.

\section{V}

According to Mounce, Hume is a 'naturalist' in the following sense. Scepticism is engendered when human reason transgresses its natural boundaries. 'Reason is cogent only when it derives its power from our natural beliefs'. ${ }^{89}$ 'Reason ... cannot undermine the [natural] belief without undermining itself'.$^{90}$ Scepticism is absurd, because 'it seeks in the name of reason to undermine the beliefs or principles on which reason itself depends'. ${ }^{91}$

How do natural beliefs (principles) constrain the deliverances of reason? Not by delimiting possible experience: we can easily imagine a non-uniform nature, for instance. But not only does the naturalist fail to explain why these beliefs have a privileged epistemological status, he concedes, Mounce acknowledges, ${ }^{92}$ the soundness of the sceptical argument, whose conclusion, as Hume formulates it, is that '[i]n every judgement', ${ }^{93}$ 'all the rules of logic require a continual diminution, and at last a total extinction of belief and evidence'. ${ }^{94}$ So how do natural beliefs evade the sceptical

${ }^{86}$ Garrett, op. cit., 234.

${ }^{87}$ D. Hume, A Treatise of Human Nature, 268.

${ }^{88}$ D. Hume, A Treatise of Human Nature, xvi.

${ }^{89}$ H.O. Mounce, Hume's Naturalism (London: Routledge, 1999), 5.

${ }^{90}$ Mounce, op. cit., 31.

${ }^{91}$ Mounce, op. cit., 31.

${ }^{92}$ Mounce, op. cit., 50.

${ }^{93}$ D. Hume, A Treatise of Human Nature, 181, my italics.

${ }^{94}$ D. Hume, A Treatise of Human Nature, 183. 
verdict? The answer is that even while we reason soundly, we may fail to arrive at the truth. ${ }^{95}$ Our 'reasoning has become autonomous and has lost connection ... with the world', ${ }^{96}$ so the sceptical conclusion is false.

This is surely incoherent. If we validly deduce a (sceptical) claim from true premises, how can our conclusion fail to be true? How can sound reasoning 'go beyond [reason's] natural limits'? ${ }^{97}$

Hume doesn't subscribe to this (incoherent) form of naturalism. He doesn't think sound arguments can yield false conclusions. It is "our uncertain reasonings and speculations' ${ }^{98}$ which may be unreliable, rather than reason as such. The rules of logic 'are certain and infallible; but when we apply them, our fallible and uncertain faculties are very apt to depart from them, and fall into error' ${ }^{99}$ 'Our reason must be consider'd as a kind of cause, of which truth is the natural effect; but such-a-one as by the irruption of other causes, and by the inconstancy of our mental powers, may frequently be prevented'. ${ }^{100}$ We fail to be persuaded by the sceptical argument although we 'can find no error in the ... arguments', ${ }^{101}$ because 'the action of the mind becomes forc'd and unnatural ... the mind reaches not its objects with easiness and facility ... there is requir'd a study and an effort of thought ... [which] disturbs the operation of our sentiments, on which the belief depends'. ${ }^{102}$ Nature here prevents us from embracing a true (sceptical) conclusion. The sceptic isn't refuted, but rather, is shoved aside, defeated by brute force. ${ }^{103}$

\section{VI}

Owen thinks that ' $[\mathrm{r}]$ eason cannot function properly if it is considered as a faculty functioning independently of our sensitive natures' ${ }^{104} \mathrm{~A}$ 'rational creature, whose makeup lacks crucial features

${ }^{95}$ Mounce, op. cit., 52.

${ }^{96}$ Mounce, op. cit., 52.

${ }^{97}$ Mounce, op. cit., 49.

${ }^{98}$ D. Hume, A Treatise of Human Nature, my italics.

${ }^{99}$ D. Hume, A Treatise of Human Nature, 181.

${ }^{100}$ D. Hume, A Treatise of Human Nature, 181.

${ }^{101}$ D. Hume, A Treatise of Human Nature, 184.

${ }^{102}$ D. Hume, A Treatise of Human Nature, 185.

${ }^{103}$ Maybe Wittgenstein subscribes to this form of naturalism. He suggests (1969, para. 105) that some propositions constitute 'the element in which arguments have their life'.

${ }^{104}$ D. Owen, Hume's Reason (Oxford University Press, 1999), 199, my italics. 


\section{Ruth Weintraub}

of our sensitive nature' ${ }^{105}$ is akin to a person who 'has never experienced any passions or sentiments ... has never had the relevant impression from which to form the idea of virtue ... and will never be in a position to have that idea ... enlivened so as to have the belief that [someone] is virtuous'. ${ }^{106}$

The analogy is specious. A person deprived of impressions will lack the corresponding ideas, and won't even be capable of entertaining propositions in which they figure. But the person who 'fall[s] prey to the sceptical arguments [because he] ... lacks that aspect of our nature that allows us to ... react to the extra force and vivacity that characterizes beliefs ${ }^{107}$ eschews belief in propositions he understands perfectly, because they are, according to a sound sceptical argument, unjustified. He may not be fully human, but his reason is functioning perfectly!

Tel-Aviv University

${ }^{105}$ Op. cit., 200-1.

${ }^{106}$ Op. cit., 200.

${ }^{107}$ Op. cit., 201. 